\title{
Exchange Rate Regimes and Trade
}

\author{
Is Africa Different?
}

\section{Mahvash Saeed Qureshi and Charalambos G. Tsangarides*}

March 2011

\begin{abstract}
This paper revisits the link between exchange rate regimes and trade in the context of Africa's exchange rate arrangements. Applying an augmented gravity model that includes measures of currency unions and pegged regimes, the paper compares Africa's experience with that of the world. Our results suggest that both currency unions and direct pegs promote bilateral trade in Africa vis-à-vis more flexible exchange rate regimes,and that their effect is almost double for the region than that for an average country in the world sample. Further, we find evidence that the effect of conventional pegs is at least as large as that of currency unions in Africa, and that the benefits of fixed exchange rate regimes stem through channels in addition to reduced exchange rate volatility.
\end{abstract}

Keywords: currency unions, fixed exchange rate regimes, Africa

JEL classification: F31, F40

\section{Copyright (C) UNU-WIDER 2011}

*International Monetary Fund, Research Department, corresponding author: mqureshi@imf.org

This study has been prepared within the UNU-WIDER project on Africa Development: Myths and Realities, directed by Augustin Fosu.

UNU-WIDER gratefully acknowledges the financial contributions to the project by the Finnish Ministry for Foreign Affairs, and the financial contributions to the research programme by the governments of Denmark (Royal Ministry of Foreign Affairs), Finland (Finnish Ministry for Foreign Affairs), Sweden (Swedish International Development Cooperation Agency-Sida) and the United Kingdom (Department for International Development-DFID). 


\section{Acknowledgements}

We thank Atish Ghosh, Badi Baltagi, Michael Bleaney, Augustin Fosu, colleagues at the International Monetary Fund, and participants at the CSAE 2009 (Oxford University) and NEUDC 2009 (Tufts University) conferences for helpful comments and suggestions. Special thanks to Harald Anderson for generously making his data onexchange rate regime classification available to us. The views expressed in this paper are those of the authors and do not necessarily represent those of the IMF or IMF policy. All errors are the authors' responsibility.

Tables and figures appear at the end of the paper.

The World Institute for Development Economics Research (WIDER) was established by the United Nations University (UNU) as its first research and training centre and started work in Helsinki, Finland in 1985. The Institute undertakes applied research and policy analysis on structural changes affecting the developing and transitional economies, provides a forum for the advocacy of policies leading to robust, equitable and environmentally sustainable growth, and promotes capacity strengthening and training in the field of economic and social policy making. Work is carried out by staff researchers and visiting scholars in Helsinki and through networks of collaborating scholars and institutions around the world.

www. wider.unu.edu

publications@wider.unu.edu

UNU World Institute for Development Economics Research (UNU-WIDER)

Katajanokanlaituri 6 B, 00160 Helsinki, Finland

Typescript prepared by Lisa Winkler at UNU-WIDER

The views expressed in this publication are those of the author(s). Publication does not imply endorsement by the Institute or the United Nations University, nor by the programme/project sponsors, of any of the views expressed. 


\section{Introduction}

The choice of exchange rate regime and its macroeconomic implications-a welldebated subject since the collapse of the BrettonWoods system in the early 1970sgained renewed interest with a series of financial crisis in the late 1990s. The exchange rate regimes adopted by the hardesthit countries were widely believed to have played a role in triggering the crisis, which led to a greater scrutiny of exchange rate policy choices and their impact on the macroeconomy by both researchers and policy makers.

Most of the ensuing research focused on the influence of exchange rate regimes on economic growth, inflation, and macroeconomic stability. A notable exception to this is the seminal work of Rose (2000), which investigates the effect of currency unions on trade, and finds that two countries having a common currency tend to trade about three times as much as they would otherwise. Frankel and Rose (2002) further show that the growth enhancing benefits of currency unions (CUs) occur through increased trade only, and not through other channels (such as reduced inflation).

These findings have generated immense interest and controversy, and numerous studies have followed which, in general, find a smaller magnitude of the effect of CUs on trade than estimated by Rose (2000).More recently, Adam and Cobham (2007), Klein and Shambaugh (2006), and Qureshi and Tsangarides (2010) go beyond CUs, and investigate the impact of other possible exchange rate regimes on bilateral trade using the gravity model framework. They find that exchange rate regimes with lower uncertainty and transaction costs, namely, CUs and pegs, are significantly more protrade than flexible exchange rate regimes.

The objective of this paper is to revisit the link between exchange rate regimes and trade in the context of Africa, where several monetary integration initiatives are under consideration, but their feasibility has been questioned repeatedly on the basis of Mundell's (1961) optimum currency areas theory. ${ }^{1}$ A key goal of the proposed African monetary unions is to boost international trade. ${ }^{2}$ Indeed, while sharing a common currency may promote trade, it may also entail higher economic and institutional costs before and after the CU formation. Further, as is evident from the recent global financial crisis, not abiding with the institutional requisites could have destabilizing effects in the face of shocks not only for the country in question, but for the entire CU. A pertinent question therefore is whether a suitable alternative exists for Africa-one that promotes trade through lower transaction costs, exchange rate volatility and uncertainty, but retains some flexibility and places fewer demands for policy coordination—such as pegging to an anchor currency.

1 See, for example, Bénassy-Quéré and Coupet (2005), Debrun, Masson, and Pattillo (2005), and Tsangarides and Qureshi (2008).

2 The regional integration initiatives in Africa include the creation of the Economic Community of West African States, for which a second monetary area-the West African Monetary Zone-comprising non-member countries of the existing West African Economic Monetary Union is envisaged by 2015. Members of the East African Community also aim to create a currency union by 2015, and an extension of the southern Common Monetary Area, which links Lesotho, South Africa, and Swaziland to other states in the region, is also a possibility in the longrun. 
We empirically investigate the viability of conventional pegs as a possible choice for Africa to enhance bilateral trade, and benchmark the trade generating effects of both CUs and pegs for the region against the world. To this end, we construct measures of CUs and pegs using a novel dataset of the International Monetary Fund's (IMF) exchange rate regime classification, which provides information on both de jure and de facto exchange rate classifications, to account for possible discrepancies between the officially announced and practically followed regimes, and their potentially different macroeconomic implications. ${ }^{3}$

Our empirical assessment also addresses some potential econometric concerns highlighted in earlier studies particularly those pertaining to the treatment of omitted variables in bilateral trade models, and puts forward quantitative estimates obtained through a range of estimation methods including controlling for dyadic-fixed effects (with and without time-varying country-specific effects), and the Hausman-Taylor (HT) approach, which permits the estimation of time invariant variables.

Our findings based on a sample of 159 countries over 1972-2006 suggest that fixed exchange rate regimes in the form of CUs and pegs increase trade for Africa vis-à-vis more flexible exchange rate arrangements, and that this affect is almost twice as large as for an average country in the world sample. Furthermore, the effect of conventional pegs for the region appears to be at least as large as CUs. In addition, CUs and pegs appear to have an effect over and above that of exchange rate volatility indicating that other factors associated with more stable exchange rate regimes such as lower transactions costs and uncertainty also play a significant role in promoting trade. There is also some evidence of an indirect effect of pegging with an anchor currencytypically realized through the stabilization of exchange rate against other currencies pegged to the same anchor-pointing to both direct and indirect bilateral trade gains achieved from pegging for Africa. These results are robust to a variety of specifications, estimation methods, and variable definitions.

In what follows, Section 2 provides a brief background to the study. Section 3 outlines the empirical methodology adopted in the paper, and discusses relevant estimation issues. Section 4 describes the data. Section 5 presents the estimation results and the sensitivity analysis. Section 6 concludes.

\section{Background}

The literature on the impact of exchange rate regimes on economic performance, and the ability of alternative regimes to act as external shock absorbers burgeoned after the Asian crisis in the late 1990s. However, the existing studies do not provide a consensus view on the subject, with results sometimes varying according to the classification of exchange rate arrangements, the cross-country and time dimensions of the sample, model specification, and estimation methodology. For example, Ghosh et al. (1997) find no systematic differences in output growth across regimes, but their results show that pegged regimes are associated with higher investment, lower productivity growth,

3 While the de facto exchange rate regime affects actual trading costs, the de jure exchange rate regime may also have an effect on trade flows by influencing market expectations about uncertainty, risk, and inflation, particularly, in the short run. 
lowerinflation, and higher volatility of growth and employment. Ghosh, Gulde, and Wolf (2003) find that pegs and intermediate regimes improve growth and inflation performance compared to floats, but pegged regimes also increase output volatility.

In contrast, Reinhart and Rogoff (2004) show that exchange rate arrangements may be quite important for growth, trade, and inflation. Levi-Yeyati and Sturzenegger (2003) note that hard pegs (such as currency boards) and those lasting five years or more are associated with lower inflation and slower growth in developing economies, but have no effect whatsoever in industrialized economies. 4 They also show that countries with short pegs underperform floats, since they grow slower without any gains in terms of inflation. Husain, Mody, and Rogoff (2005) argue that the economic implications of different exchange rate regimes depend on the level of economic and institutional development. Their results indicate that greater exchange rate flexibility improves economic growth in advanced economies but has no effect on their inflation rates, lowers growth, and increases inflation in developing economies, and has no effect on growth and inflation in emerging economies.

In the context of trade performance, an extensive body of literature in the late 1970s, through the 1980s, examines the effect of exchange rate volatility on trade and finds mixed results (for example, Cushman 1983; Hooper and Kohlhagen 1978; Kenen and Rodrik 1986; Thursby and Thursby 1987). Studies in the following decade, for example, Frankel (1997)and Frankel and Wei (1993) are more consistent in their findings and report negative, though small effects of exchange rate volatility on trade. In his seminal work, Rose (2000) examines the issue from a different perspective and uses a gravity model of bilateral trade flows to empirically investigate the impact of CUs on trade. His results show a large effect: two countries sharing a currency tend to trade roughly three times as much as they would otherwise. Frankel and Rose (2002), Glick and Rose (2002), and Rose and van Wincoop (2001) confirm this result, and show that it is robust to various specifications and estimation techniques. Other studies have, however, challenged the size of the effect reported by Rose (2000) on methodological grounds, but generally agree with the existence of a commoncurrency effect on trade. 5

Some recent studies go beyond CUs, and investigate the impact of other possible exchange rate regimes on bilateral trade using the gravity model framework. For example, Klein and Shambaugh (2006) use the de facto exchange rate regime classification developed by Shambaugh (2004) for the period 1973-99 to estimate the impact of CUs, and de facto direct and indirect pegged exchange rate arrangements on bilateral trade flows. They report statistically significant gains from CUs and direct pegs, but not a strong impact of indirect pegs on trade. Consistent with earlier studies, they also report a negative albeit small and diminishing effect of exchange rate volatility on trade. Using Reinhart and Rogoff's (2004) de facto exchange rate regime classification, Adam and Cobham (2007) construct 27 different bilateral exchange rate arrangements for countries over 1948-98, and show that regimes with lower exchange

4 Levi-Yeyati and Sturzenegger (2003) note that in economies with short-run price rigidities, exchange rate flexibility facilitates resource allocation in the face of real shocks, thereby improving growth prospects. Broda (2001) and Edwards and Levy-Yeyati (2005) support this finding and respectively show that the inability of rigid regimes to absorb shocks results in more volatile output paths and lower growth.

5 See, for example, Nitsch (2002), Tenreyro (2001), and Tsangarides et al. (2009). 
rate uncertainty and transactions costs are significantly more pro-trade than the floating regime. 6

For Africa, Masson and Pattillo (2004) examine the impact of CUs on trade and find that they increase trade three-fold for the region. Tsangarides et al. (2009) support these findings and show that CU membership benefits Africa as much as the rest of the world. In addition, they find evidence that CUs are associated with trade creation, and increased price co-movements among member countries, and that the duration of CU membership matters for trade: longer duration brings about greater benefits, but with some diminishing returns.

\section{Methodology}

In line with recent literature, we employ the gravity model of trade to investigate the effects of exchange rate regimes on trade. The gravity model represents trade between two economies as a function of their respective economic masses and trading costs (commonly proxied by the distance between them). The basic model has been extended in recent years to incorporate a variety of other factors that may affect trading costs, for example, trade agreements, common language, historical ties, common border, geographical location, and so forth. To the extent that exchange rate policy influences currency conversion costs, exchange rate volatility as well as uncertainty, trading costs would also depend on the exchange rate regime in place such that more stable exchange rate regimes are expected to reduce these costs and affect bilateral trade.

We augment the conventional gravity model with measures of fixed exchange rate regimes, specifically, CUs and pegs, and estimate the benchmark specification of the following form

$$
\log \left(X_{i j t}\right)=\beta_{0}+\sum_{k=1}^{N} \beta_{k} Z_{i j t}+\gamma C U_{i j t}+\delta \operatorname{DirPeg}_{i j t}+\lambda_{t}+v_{i j}+u_{i j t}
$$

where $X_{i j t}$ denotes real bilateral trade between countries $i$ and $j$ in year $t, C U$ is a binary variable that is unity if $i$ and $j$ share a currency,DirPeg is also a binary variable that is unity if $i$ 's exchange rate is pegged to $j$, or vice versa (but $i$ and $j$ are not members of the same $\mathrm{CU}$ ), and $Z$ is a vector consisting of traditional time-variant and invariant determinants. The time-variant variables include the (log of) product of real gross domestic product (GDP) of the trading partners, the (log of) product of their real GDP per capita, and a binary variable equal to one if the two countries share a free trade agreement. The time invariant variables include the (log of) bilateral distance, the (log of) product of geographical areas of the dyad, binary variables for the existence of common historical, geographical, and linguistic ties, and the number of landlocked and island countries in the pair. 7

6 Brada and Mendez (1988) use a limited sample of countries for the 1970s, and find a negative impact of pegs on international trade. However, Fritz-Krockow and Jurzyk (2004) examine the effect of pegs and CUs for the Latin American and Caribbean countries, and find a positive impact of the latter, but no effect of the former on bilateral trade.

7 See Appendix table A1 for a detailed description of the variables and data sources. 
In addition, equation (1) includes dyad-specific effects $\left(v_{\mathrm{ij}}\right)$-discussed in detail below-to account for any pro-trade omitted variables that are correlated with the explanatory variables, year-specific effects $\lambda_{t}$ to control for any common shocks across countries over time, and a random error term $\left(u_{i j} \sim \mathrm{N}(0, \sigma)\right.$.

Recognizing that both CUs and DirPeg may improve trade through channels other than reduced exchange rate volatility (such as lower transaction costs and uncertainty), we also include a measure of real exchange rate volatilityVol in equation (1) to empirically determine the significance of these other channels. Further, while the variable DirPeg indicates the peg between a country's currency to a reference currency, this peg may lead to the stabilization of exchange rates vis-à-vis several other countries simultaneously, thereby generating other (indirect) peg relationships. Thus, for example, if two countries (B and C) are pegged to the same anchor (A), their currencies would be also stable relative to each other. Similarly, if another country, D, is pegged to $B$, then $D$ would also have an exchange rate link with countries A and C, and so forth. To take into account such indirect peg relationships generated by a single peg, we create another binary variableIndPeg $g_{i j}$ which takes the value of 1 if $i$ is indirectly related to $j$ through its peg with an anchor country, and zero otherwise, and extend equation (1) as follows8

$$
\log \left(X_{i j t}\right)=\beta_{0}+\sum_{k=1}^{N} \beta_{k} Z_{i j t}+\gamma C U_{i j t}+\delta \operatorname{DirPeg}_{i j t}+\varepsilon \operatorname{IndPeg}_{i j t}+\varsigma \operatorname{Vol}_{i j t}+\lambda_{t}+v_{i j}+u_{i j t}
$$

where following Ghosh,Gulde, and Wolf(2003)Vol is defined over a specific horizon $n$ and is constructed in two steps. First, for each month in a given year, we take the absolute value of the percentage change in the bilateral real exchange rate $R$ over the previous $n$ months. Next, the average of the absolute values over $n$ months is taken to obtain a measure corresponding to that particular year, given by

$$
\mathrm{Vol}_{t}=\sum_{p=1}^{n} \frac{\left|R_{t+p-1}-R_{n+p-1}\right|}{n}
$$

wheren represents two horizons-12 and 36 months - to represent short- and long-run volatility, respectively.

The anchor currencies that we consider for the construction of both DirPeg and IndPeg variables include twelve international, as well as regionally important currencies (Australian Dollar, Belgian Franc, Deutsche Mark, French Franc, Indian Rupee, New Zealand Dollar, Portuguese Escudo, Pound Sterling, Russian Ruble, Singapore Dollar, Spanish Peseta, and South African Rand). We focus on strict exchange rate anchors, whereby countries serving as anchors of monetary policy or multiple anchors (basket pegs) are not included.

Further, since the depth or level of the indirect peg relation between a trading pair may imply a different impact on trade, we use two alternative coding schemes for indirect pegs. In the first scheme, we include the shortest indirect linkage where a dyad pegged to the same base is considered as having an indirect peg. In the second scheme, we

8 The definition of indirect pegs used here is similar to that in Klein and Shambaugh (2006) and Qureshi and Tsangarides (2010). See Appendix figure A1 for a graphical illustration. 
include longer indirect linkages, such as those between two countries that are pegged to different anchor currencies, but their anchor currencies are pegged to the same anchor country.9 Overall, the three exchange rate regime categories included in our estimation-currency unions, direct pegs, and indirect pegs-are mutually exclusive such that at a point in time, each country pair is coded as one of the three.

\subsection{Estimation issues}

Estimation of the gravity model raises several methodological issues that have been discussed extensively in the literature, foremost being the potential endogeneity of regressors, essentially arising from their correlation with the error term. There are two possible sources of this correlation: omitted variables and reverse causality.

The pooled ordinary least squares (OLS) approach essentially assumes that there is no unobserved individual heterogeneity across countries. However, if such heterogeneity exists, and strongly affects bilateral trade as well as the regressors included in the gravity model, then the error term would be correlated with $Z_{k}$ and the OLS estimator is likely to be biased and inconsistent. Research following Rose (2000) attempts to control for this bias by introducing country-specific effects (CFE) in the gravity model-both for cross-sectional and panel estimations, but Glick and Rose (2002) argue that including CFE may still not resolve the omitted variables problem. This is because the unobserved variables could be correlated with the bilateral characteristics of the dyads (such as the propensity to opt for a particular exchange rate regime), as well as the trade between them, which may bias the CFE estimates. Glick and Rose (2002) therefore propose adding countrypair-specific effects (CPFE) to the gravity equation, thereby controlling for any strong bilateral likelihood to trade.

Estimating the gravity model with the CPFE, however, does not provide coefficient estimates for the time invariant variables. An alternative-which addresses concerns related to omitted variables, and the estimation of time invariant (or with little variation) regressors - is the Hausman and Taylor (1981) estimation technique. The HT estimator-based on the instrumental variable approach-yields consistent and efficient estimates in the presence of correlation between some explanatory variables and the error term, and is considered to outperform the OLS, random and fixed effects methods when applied to gravity models (see, for example, Egger and Pfaffermayr2003 and Serlenga and Shin 2007).10

The second potential source of endogeneity in equation (1) stems from the dependence of exchange rate regime itself on trade links between countries. While this source of endogeneity may be an important issue in cross-sectional studies, an advantage of using the panel specification is that it could be addressed through the inclusion of dyadspecific effects. Taking into account the dyadic-fixed effects captures the impact of all

9 Specifically, the first definition of indirect peg includes relation=2 between pairs in Appendix figure A1. The second definition includes indirect relations $=2,3,4$, and 5. The results for the second definition are presented in the sensitivity analysis.

10 The HT approach instruments the endogenous time-varying variables with the deviation from their means, and the endogenous time invariant variables with the deviation of the exogenous time-varying variables from their means. The set of endogenous variables could be determined by a Hausman-test, which is based on the comparison of the HT estimator with the within (fixed effects) estimator (Baltagi 2001). 
time-invariant factors that are specific to the trading partners, but are likely to affect their trade as well as the exchange rate arrangement between them. This makes the assumption of exogenous exchange rate regime, that is, countries do not base their exchange rate policy choices in response to random shocks to trade, much more plausible.11 Nevertheless, to address any concerns that the exchange rate regime responds to changes in trade due to time-varying bilateral effects not controlled for in the regression, we also estimate equation using the system generalized method of moments (GMM) estimator in the sensitivity analysis.

\section{Data}

An important issue in the empirical study of exchange rate regimes is that of regime classification. Early literature used the de jure classification - the regime declared by national authorities, and published in the IMF's Annual Report on Exchange Arrangements and Exchange Restrictions. However, since pervasive differences were highlighted between the officially announced and practically followed (or de facto) regimes, the use of the former in empirical analysis has been significantly reduced. Thereafter, de facto classifications that seek to categorize regimes based on movements in the exchange rate or international reserves have been developed-the best known of which include the IMF's de facto classification published since 1999, Ghosh, Gulde, and Wolf(2003), Levi-Yeyati and Sturzenegger (2003), Reinhart and Rogoff (2004), and Shambaugh (2004).

In our empirical analysis, we employ the IMF's de facto classification schemeextended backwards for the period 1972-99 by Bubula and Ötker (2003) and Anderson (2008) — which offers two notable advantages. First, it is the only available de facto classification which combines available information on a central bank's policy framework with the actual exchange rate and foreign reserves movements to form a judgment about the exchange rate regime in place. In this respect, it is the only de facto classification that takes into account central bank behaviour in addition to exchange rate behaviour, where the necessary information is compiled from primary and secondary sources. Second, the available cross-country and time coverage for IMF's de facto classification is similar to that of the de jure classification, which ensures that any differences in results between the two are not driven by variation in country coverage or time period. 12

A quick look at the IMF's de jure and de facto exchange rate regime classification for the world and Africa samples reveals two interesting features (Figure 1). First, for both samples, the share of fixed exchange rate regime in the de facto classification is consistently higher than in the de jure classification, supporting the 'hidden pegs' hypothesis of Levi-Yeyati and Sturzenegger (2003). Consequently, the share of de facto floating regimes is lower than the de jure floats throughout, as suggested by Calvo and

11 In the context of CUs in Africa, the assumption of exogeneity is even more plausible considering that the decision to be a CU member have been driven largely by political considerations (Masson and Pattillo 2004).

12 The de jure classification, officially available until 1998, has been updated by Anderson (2008) up to 2007. For a detailed comparison of IMF's de facto classification with other available classifications, see Qureshi and Tsangarides (2010). 
Reinhart's (2002) 'fear of floating' hypothesis. Second, the share of fixed exchange rate regime in both samples appears to have declined over the 1990s, but risen again in recent years. Specifically, about 60 percent of the countries in Africa had a fixed exchange rate regime (CU or peg) in place in 2006, which represents an increase of about 10 percentage points from the previous decade.

Combining the regime classification for individual countries with the information on anchor currencies obtained from Anderson (2008), we construct bilateral binary variables for CUs, direct pegs and indirect pegs, which indicate if a country had a stable exchange rate regime vis-à-vis its trading partner in a particular year. We merge this data with the annual bilateral trade data obtained from the IMF's Direction of Trade Statistics, and obtain a bilateral dataset covering 159 countries over 1972-2006, which yields 10,894 individual country pairs, and 177,270 observations, about 40 per cent of which belong to the Africa sample.13

Table 1 presents the distribution of CUs, direct pegs, and indirect pegs in the dyadic dataset used for estimation purposes. In the full sample, the number of observations coded as de facto pegs is higher than de jure pegs. Since one direct peg can generate several indirect pegs, we have 8,092 and 16,705 indirect pegs based on the de jure and de facto classifications, respectively. About 40 per cent of observations coded as direct pegs have at least one trading partner in the African region, while about 70 per cent of observations coded as sharing a common currency belong to Africa.

\section{Empiricalresults}

For completeness and comparative purposes, we estimate the benchmark and extended models with the pooled OLS, CPFE, and HT estimators using both the de jure and de facto classifications.14 Since our dataset pools a large number of country pairs over about 30 years, the error term is likely to exhibit correlation patterns for given country pairs. To take this into account, we cluster the standard errors at the country pair level in all estimations.

The estimation results for the benchmark specification with both de jure and de facto classifications are presented in Tables 2 and 3, respectively. In both cases, for the OLS estimation when only time effects are included along with the other gravity variables, CUs and direct pegs have a significantly positive effect on bilateral trade, with the effect of CUs being considerably larger than direct pegs in both samples. The signs and magnitude of the estimated coefficients of the traditional gravity variables are plausible and in line with earlier studies, and a majority of these variables are statistically significant at the 1 per cent level.

Controlling for the dyad-specific effects as in CPFE, we observe that the estimated trade generating effects of CUs and direct pegs fall substantially for the world sample but

13 The full sample covers all countries for which the required data are available, while the Africa sample comprises those observations where at least one trading partner is in Africa.

14 We also estimate the benchmark specification with the random effects model. However, in all cases, the Hausman-test-based on the differences between the fixed and random effects models_fails to confirm the hypothesis that the explanatory variables are uncorrelated with the unobserved omitted variables. 
remain statistically significant. For Africa, the CU effect drops but that of direct pegs increases - interestingly, the direct effect of conventional pegs is almost 1.5 times larger than the CU effect. Nevertheless, using the CPFE approach we lose the cross-sectional information of the data, and all time invariant variables drop from the estimation. To take into account the cross-sectional dimension while allowing for the correlation of some regressors with the individual effects, we estimate equation (1) with the HT approach. The Hausman-test results (as reported in the last row of Tables 2 and 3) suggest that the difference between the CPFE and HT estimators is not significant enough to reject the appropriateness of the HT estimator, which is thus our preferred estimator here.

The estimated trade generating effect of CUs and direct pegs based on the HT method is quite similar to that obtained from the CPFE approach. We interpret the estimated coefficients to indicate that the membership of a CU, on average, increases bilateral trade for an average country in the world sample by about 35 per cent.This result is in line with the estimates of recent studies, which report a smaller effect than Rose (2000). Both de jure and de facto direct pegs have a significantly positive effect on bilateral trade, with the size of the estimated effect for the world sample (35-37 per cent) being close to that of CUs.

The HT estimation results for the de jure and de facto classifications for the Africa sample are broadly similar, and indicate that the trade generating effects of fixed exchange rates are on average more than double for Africa than for the world. Further, the effect of direct pegs appears to be at least as large as CUs for Africa. Thus, for example, CUs increase trade by almost 100 per cent between African trading partners, while direct pegs increase trade by about 130 per cent between an average African country in the sample with its anchor country.

Next, we estimate the extended specification including the measures of exchange rate volatility and indirect pegs. The results reported in Tables 4 and 5 indicate that the estimated impact of long-run exchange rate volatility is significantly negative for both samples, but the impact is larger for Africa as compared to an average country in the world sample. Notably, the estimated positive impacts of both CUs and direct pegs remain statistically significant despite controlling for exchange rate volatility, supporting the finding of earlier studies and indicating that more stable exchange rate regimes promote trade through channels in addition to reduced exchange rate volatility.

The impact of indirect pegs appears be strongly negative for the world sample. This result, somewhat surprising, is similar to that obtained by Klein and Shambaugh (2006) and Qureshi and Tsangarides (2010). The latter, however, observe that the negative effect stems from the indirect pegs generated through the US dollar, which largely comprise non-industrialized dyads that are geographically located far apart (for example, those between trading partners in East Asia and Latin America). This is in contrast to the indirect pegs generated through, for example, the Deutsche Mark and the French Franc that are mostly between trading partners in Europe and Africa, with comparatively smaller distances. Geographical location could play an important role in determining the effect of indirect pegs as the benefits associated with greater exchange 
rate stability vis-à-vis the partner countries may diminish if other trading costs, such as transportation and information, increase. 15

This explanation appears plausible in our case since we observe the effect of indirect pegs - largely generated through the French Franc - to be positive for Africa. This is true for both the de jure and de facto classification though the effect is statistically significant for the former classification only.

\subsection{Sensitivity analysis}

The results presented in Tables 2 to 5 verify the robustness of our estimates to various estimation methods (for example, OLS, CPFE, and HT). However, several other concerns pertaining to model specification, methodology, variable definitions, and sample coverage raised in earlier literature may be relevant to our analysis. In what follows, we attempt to address these concerns through a range of sensitivity checks for the Africa sample, and report the results in Table 6.

\subsubsection{Alternate variable definitions}

The results reported in Table 6 (column 1) show that using the measure of short-run exchange rate volatility (defined over a one-year period) instead of long-run volatility in equation (1) does not alter the results in a significant manner. The estimated coefficients of both CUs and direct pegs retain statistical significance, but the estimated coefficient of short-run exchange rate volatility is somewhat smaller than long-run volatility indicating that exchange rate volatility over a long horizon is more damaging for trade activity.

Table 6 (column 2) presents the results of the extended specification with an alternate definition of exchange rate volatility, defined as the standard deviation of the first difference of (logs of) the real exchange rate, and given by

$\operatorname{Vol} 2_{t}=S D\left[r_{t+p-1}-r_{t+p-2}\right]$,

where $r$ is the natural log of bilateral real exchange rate between countries $i$ and $j$, and the first difference is computed over one month (with end-of-month data), while the standard deviation is calculated over 36 months to measure long-run volatility. The results show that using Vol2 does not affect the estimated coefficients of CUs and pegs in a significant manner, and the effect of exchange rate volatility also remains significantly negative.

Reassuringly, the results are also robust to an alternate measure for indirect pegs, which includes more distant relationships created through pegging with an anchor currency (specifically, relations $=3,4$ and 5 in Appendix figure A1). Table 6 (column 3) shows that the positive effect of indirect pegs for Africa holds though the magnitude of the

15 Qureshi and Tsangarides (2010) examine if the effect of indirect pegs is conditional on distance by including an interaction term of indirect pegs and bilateral distance, and find support for the conjecture that geographical distance dampens the effect of exchange rate stability created through indirect peg relationships. 
estimated coefficient of indirect pegs becomes smaller indicating, as expected, lower benefits from more distant indirect links created through pegging.

\subsubsection{Alternate model specification}

To address concerns related to the non-linear relationship between trade and output, and exchange rate volatility, we modify our extended specification to allow for a non-linear relationship between bilateral trade and exchange rate volatility as well as with log of real GDP. The results reported in columns (4) and (5) of Table 6 show that this has no effect whatsoever on the estimation results for CUs, DirPeg, and IndPeg for both de jure and de facto classifications, though the quadratic term for exchange rate volatility is significantly positive indicating that the effect of exchange rate volatility on bilateral trade tapers off gradually as volatility increases.

\subsubsection{Simultaneity concerns}

Next, we address any simultaneity concerns using the system GMM estimatorproposed by Blundell and Bond (1998)—which transforms the model by taking first differences to eliminate the fixed effects and supplements it with the levels equation (using lagged levels as instruments for the differenced equation, and lagged differences as instruments for the levels equation). The results, presented in Table 6 (column 6), show that the strong positive impact of fixed exchange rate arrangements on bilateral trade is robust to GMM estimation and the dynamic panel specification of the model. For both the de jure and de facto classifications, the coefficients for $\mathrm{CU}$ and direct pegs are significantly positive. However, the estimated coefficient for exchange rate volatility, though negative, is statistically insignificant.16

\subsubsection{Alternate exchange rate regime classification}

Taken together, the estimates reported through Tables 2 to 6 suggest that CUs in Africa increase bilateral trade in the range of about 50-115 percent, while (de jure and de facto) direct pegs promote trade by about 115-55 per cent. These estimates are, however, based on the IMF exchange rate regime classification, and may be sensitive to other available exchange rate regime classifications. To test the robustness of our results to the regime classification, we use the de facto classification developed by Shambaugh (2004). Specifically, Shambaugh (2004) considers a country to have a pegged regime in place, if in a given calendar year, that country's monthly official bilateral exchange rate remains within a 2per cent band of a 'base' currency (and a non-peg otherwise). Hence, in contrast to the IMF's de facto classification, Shambaugh (2004) categorizes the regime solely based on the actual behaviour of the exchange rate. 17

16 In addition, we also use alternate samples which exclude oil exporters, small states with populations less than one million, and other estimation methods to take into account the zero trade observations such as the Tobit method. The results for these exercises not reported here for brevity, indicate that the estimated effects of CUs and direct pegs for both the world and Africa samples are reassuringly robust. All results are available upon request.

17 Considerable differences appear to lie in the coding of direct (and consequently indirect) pegs between the IMF's de facto and Shambaugh's classifications, with the latter in general generating more peg 
The results obtained from this alternate classification for the Africa sample are presented in the last column of Table 6. The estimated coefficients for the CU and direct peg dummy variables are significantly positive, but the effect of indirect pegs in this case is weakly negative. Although the magnitude of the estimated coefficient for the direct peg variable appears smaller, we are unable to reject the hypothesis of the equality of both coefficients through an F-test, which supports the result obtained earlier that the effect of direct pegs, is at least as large as CUs for Africa. Further, the results for the world sample (not reported here) are very similar to those reported in Table 5in particular, the effect of fixed exchange rate regimes on bilateral trade appears to be larger for Africa than for the world sample.

\section{Conclusion}

This paper empirically examines the effect of monetary unions vis-à-visconventional peg regimes on Africa's bilateral trade using both de jure and de facto classifications over 1972-2006. Our analysis, based on an augmented version of the gravity model, shows that currency unions, direct pegs and reduced exchange rate volatility have a strong impact on Africa's trade, which is almost twice as large as for an average country in the world sample. This suggests that in the context of trade, African countries stand to benefit substantially from the adoption of fixed exchange rate regimes. In addition, we find that the trade-generating effect of direct pegs for the region is at least as large as CUs, and some evidence of beneficial indirect gains achieved through pegging as well.

From a policy perspective, the positive and relatively large effect of direct pegs for Africa may have important implications for the ongoing debates on regional currency union formation, a subject that is at the forefront of economic policy agendas across Africa. Viewed in the context of the policy option to choose hard or soft pegs, countries aspiring to expand cross-border trade activity through more stable exchange rate regimes while retaining some flexibility, could consider pegs as a viable alternative to complete monetary integration.

relationships. In the dyadic sample, for example, there is agreement on only 36 percent of the observations for direct pegs. 


\section{Appendix}

Appendix table A1: Variable description and data sources

\begin{tabular}{|c|c|c|}
\hline Variable & Description & Source \\
\hline \multicolumn{3}{|l|}{$\begin{array}{l}\text { Dependent } \\
\text { variable }\end{array}$} \\
\hline Irtrade $_{i j t}$ & $\begin{array}{l}\text { Log of the average value of } \\
\text { real bilateral trade between } \mathrm{i} \\
\text { and } \mathrm{j} \text { at time } \mathrm{t}\end{array}$ & $\begin{array}{l}\text { IMF's Direction of Trade (DoT): Average of exports from } a \\
\text { to } b \text {, and } b \text { to } a \text {; and import into a from } b \text {, and to } b \text { from } a \text {. } \\
\text { Deflated by US CPI for urban consumers }\end{array}$ \\
\hline \multicolumn{3}{|c|}{ Explanatory variables } \\
\hline $\mathrm{CU}_{\mathrm{ijt}}$ & $\begin{array}{l}\text { Binary variable which is unity if } \\
\mathrm{i} \text { and } \mathrm{j} \text { share currency at time } \mathrm{t}\end{array}$ & Anderson (2008) \\
\hline $\begin{array}{l}\text { Direct peg } \\
\text { (de jure) }_{\mathrm{ijt}}\end{array}$ & $\begin{array}{l}\text { Binary variable which is unity if } \\
i \text { and } j \text { are pegged to each } \\
\text { other at time } t\end{array}$ & Anderson (2008) \\
\hline $\begin{array}{l}\text { Direct peg } \\
\text { (de facto) })_{\mathrm{ijt}}\end{array}$ & $\begin{array}{l}\text { Binary variable which is unity if } \\
i \text { and } j \text { are pegged to each } \\
\text { other at time } t\end{array}$ & Anderson (2008) \\
\hline Volatility & Exchange rate volatility & Information Notice System \\
\hline $\operatorname{Lrgdp}_{i j t}$ & $\begin{array}{l}\text { Log of the product of real GDP } \\
\text { of } i \text { and } j \text { at time } t\end{array}$ & World Bank's World Development Indicators (WDI) \\
\hline $\operatorname{Lrgdp}_{i j t}$ & $\begin{array}{l}\text { Log of the product of real GDP } \\
\text { per capita of } i \text { and } j \text { at time } t\end{array}$ & $W D I$ \\
\hline Ldist $_{i j}$ & $\begin{array}{l}\text { Log of the distance between } \mathrm{i} \\
\text { and } \mathrm{j}\end{array}$ & CEPII(http://www.cepii.fr/anglaisgraph/bdd/distances.htm) \\
\hline Ldist_cap $_{i j}$ & $\begin{array}{l}\text { Log of the distance between } \\
\text { capital cities of } i \text { and } j\end{array}$ & CEPII(http://www.cepii.fr/anglaisgraph/bdd/distances.htm) \\
\hline Ldist_wces $i j$ & $\begin{array}{l}\text { Log of population weighted } \\
\text { distance between the largest } \\
\text { cities of } i \text { and } j\end{array}$ & CEPII(http://www.cepii.fr/anglaisgraph/bdd/distances.htm) \\
\hline Lang $_{i j}$ & $\begin{array}{l}\text { Binary variable which is unity if } \\
\mathrm{i} \text { and } \mathrm{j} \text { have a common } \\
\text { language }\end{array}$ & Tsangarides et al. (2009) \\
\hline Comborder $_{\mathrm{ij}}$ & $\begin{array}{l}\text { Binary variable which is unity if } \\
i \text { and } j \text { share a land border }\end{array}$ & Tsangarides et al. (2009) \\
\hline Landl & $\begin{array}{l}\text { Number of landlocked } \\
\text { countries in the country-pair } \\
(0,1 \text {, or } 2)\end{array}$ & Tsangarides et al. (2009) \\
\hline Island & $\begin{array}{l}\text { Number of island nations in } \\
\text { the country-pair }(0,1 \text {, or } 2)\end{array}$ & Tsangarides et al. (2009) \\
\hline
\end{tabular}




\begin{tabular}{|c|c|c|}
\hline Larea $_{i j}$ & $\begin{array}{l}\text { Log of product of land area of } i \\
\text { and } j\end{array}$ & Tsangarides et al. (2009) \\
\hline Comcol $_{\mathrm{ij}}$ & $\begin{array}{l}\text { Binary variable which is unity if } \\
\text { i and j were colonies after } \\
1945 \text { with the same colonizer }\end{array}$ & Tsangarides et al. (2009) \\
\hline Curcol $_{i j}$ & $\begin{array}{l}\text { Binary variable which is unity if } \\
i \text { and } j \text { are colonies at time } t\end{array}$ & Tsangarides et al. (2009) \\
\hline Evercol $_{\mathrm{ij}}$ & $\begin{array}{l}\text { Binary variable which is unity if } \\
\text { i colonized j or vice versa }\end{array}$ & Tsangarides et al. (2009) \\
\hline Comcty $_{\mathrm{ij}}$ & $\begin{array}{l}\text { Binary variable which is unity if } \\
i \text { and } j \text { remained part of the } \\
\text { same nation during the sample }\end{array}$ & Tsangarides et al. (2009) \\
\hline $\mathrm{Fta}_{\mathrm{ij}}$ & $\begin{array}{l}\text { Binary variable which is unity if } \\
i \text { and } j \text { belong to the same } \\
\text { regional trade agreement }\end{array}$ & WTO(http://rtais.wto.org/UI/PublicMaintainRTAHome.aspx) \\
\hline
\end{tabular}

Appendix figure A1: Direct and indirect peg relations across countries

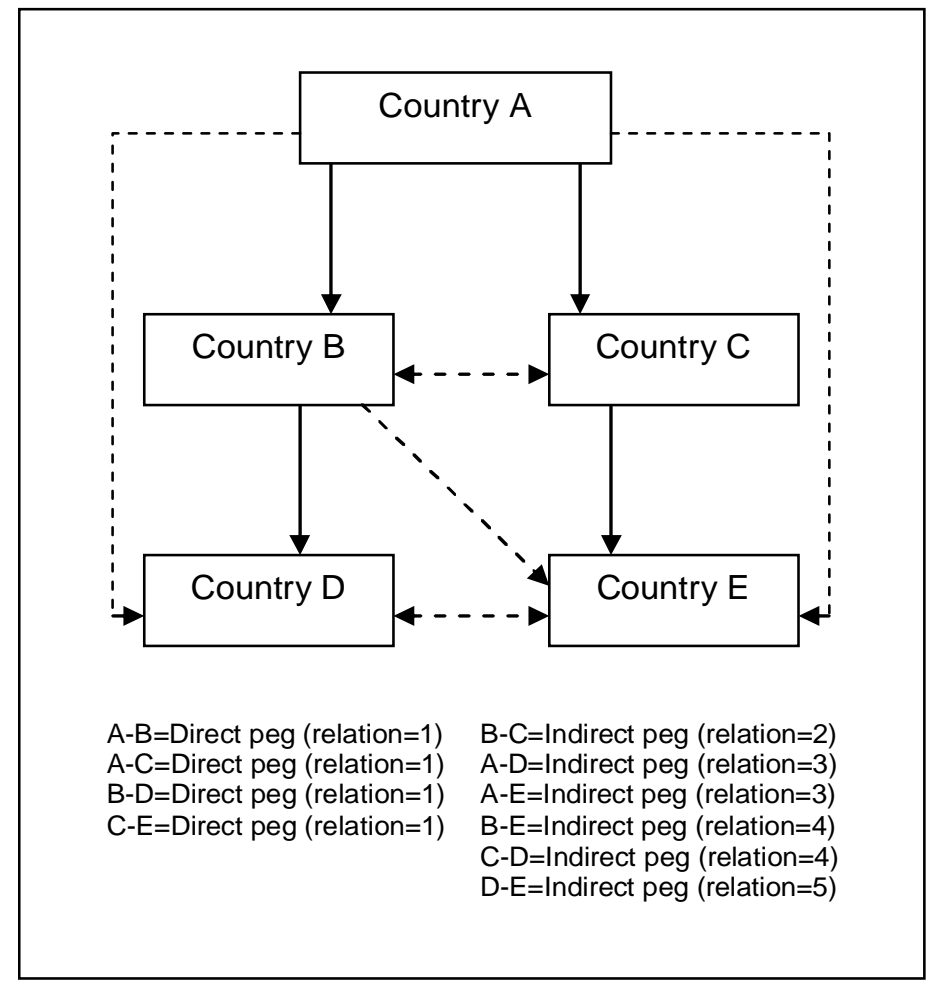

Source: Qureshi and Tsangarides (2010). 


\section{References}

Adam, C. and D. Cobham(2007).'Exchange Rate Regimes and Trade'.The Manchester School, 75: 44-63.

Anderson, H. (2008). 'Exchange Policies before Widespread Floating (194589)'.Unpublished manuscript. Washington, DC: International Monetary Fund.

Baltagi, B. (2001).Econometric Analysis of Panel Data, 2nd edition. Bognor Regis: Wiley.

Bénassy-Quéré, A., and M. Coupet (2005).'On the Adequacy of Monetary Arrangements in Sub-Saharan Africa’. World Economy, 28: 349-73.

Blundell, R.W., and S.R. Bond (1998). 'Initial Conditions and Moment Restrictions in Dynamic Panel Data Models’. Journal of Econometrics, 87: 115-43.

Brada, J., and J.A. Mendez (1988). 'Exchange Rate Risk, Exchange Rate Regime and the Volume of International Trade’. Kyklos,41 (2): 263-80.

Broda, C. (2001). 'Coping with Terms of Trade Shocks: Pegs versus Floats'.American Economic Review, 91 (2): 376-80.

Bubula, A., and I. Ötker (2003). 'Are Pegged and Intermediate Regimes More Crisis Prone?’. Working Paper 03/223. Washington, DC: International Monetary Fund.

Calvo, G., and C.M. Reinhart (2002).'Fear of Floating'.Quarterly Journal of Economics, 107: 379-408.

Cushman, D. O. (1983). 'The Effects of Real Exchange Rate Risk on International Trade’. Journal of International Economics, 15: 45-63.

Debrun, X., P. Masson, and C. Pattillo (2005). 'Monetary Union in West Africa: Who MightGain, Who Might Lose, and Why?’. Canadian Journal of Economics, 38: 454-81.

Edwards, S. and E. Levy-Yeyati (2005). 'Flexible Exchange Rates as Shock Absorbers'. European Economic Review, 49 (8): 2079-105.

Egger, P., and M. Pfaffermayr (2003). 'The Proper Panel Econometric Specification for the Gravity Equation: A Three-Way Model with Bilateral Interaction Effects'. Empirical Economics,28 (3): 571-80.

Frankel, J. (1997). Regional Trading Blocs in the World Economic System. Washington, DC:Institute for International Economics.

Frankel, J.A., and S.J. Wei (1993).'Trade Blocks and Currency Blocks’. Working Paper 4345. Cambridge, MA: National Bureau of Economic Research.

Frankel, J.A., and A.K. Rose, (2002). 'An Estimate of the Effect of Common Currencies on Trade and Income’. Quarterly Journal of Economics, 117: 437-66.

Fritz-Krockow, B., and E. Jurzyk (2004). 'Will You Buy My Peg? The Credibility of a Fixed Exchange Rate Regime as a Determinant of Bilateral Trade’. Working Paper 04/165.Washington, DC: International Monetary Fund.

Ghosh, A., A. Gulde, and H. Wolf (2003).Exchange Rate Regime: Choices and Consequences. Cambridge, MA: MIT Press. 
Ghosh, A., A. Gulde, J. Ostry, and H. Wolf(1997). 'Does the Nominal Exchange Rate Regime Matter?’.Working Paper 5874.Cambridge, MA: National Bureau of Economic Research.

Glick, R., and A. Rose (2002). 'Does a Currency Union Affect Trade? The Time-series Evidence'. European Economic Review, 46: 1125-51.

Hausman, J., and W.E. Taylor (1981).'Panel Data and Unobservable Individual Effects’. Econometrica,49 (6): 1377-98.

Hooper, P., and S.W. Kohlhagen (1978). 'The Effect of Exchange Rate Uncertainty on the Prices and Volume of International Trade’.Journal of International Economics, 8: 483-511.

Husain, A., A. Mody, and K. Rogoff (2005). 'Exchange Rate Regime Durability and Performance in Developing versus Advanced Economies’.Journal of Monetary Economics, 52: 35-64.

Kenen, P., and D. Rodrik (1986). 'Measuring and Analyzing the Effects of Short-term Volatility in Real Exchange Rates'.Review of Economics and Statistics, 68: 311-5.

Klein, M., and J. Shambaugh (2006).'Fixed Exchange Rates and Trade'. Journal of International Economics, 70: 359-83.

Levy-Yeyati, E., and F. Sturzenegger(2003).'To Float or to Fix: Evidence on the Impact of Exchange Rate Regimes on Growth'. American Economic Review, 93 (4): 117393.

Masson, P., and C. Pattillo (2004).The Monetary Geography of Africa. Washington, DC: Brookings Institution.

Mundell, R.A. (1961). 'A Theory of Optimum Currency Areas'. American Economic Review, 53: 657-64.

Nitsch, V. (2002). 'Honey, I Shrunk the Currency Union Effect on Trade’.The World Economy, 25 (4): 457-74.

Qureshi, M.S., and C. Tsangarides (2010).'The Empirics of Exchange Rate Regimes and Trade: Words vs. Deeds'. Working Paper 10/48. Washington, DC: International Monetary Fund.

Reinhart, C., and K. Rogoff (2004). 'A Modern History of Exchange Rate Regimes: A Reinterpretation'.Quarterly Journal of Economics, 119 (1): 1-48.

Rose, A.K. (2000). 'One Money One Market: Estimating the Effect of Common Currencies on Trade’. Economic Policy, 15: 7-46.

Rose, A.K., and E. van Wincoop (2001). 'National Money as a Barrier to International Trade: The Real Case for Currency Union’. American Economic Review, 91(2)38690.

Serlenga, L., and Y. Shin (2007). 'Gravity Models of Intra-EU Trade: Application of the CCEP-HT Estimation in Heterogeneous Panels with Unobserved Common Timespecific Factors'. Journal of Applied Econometrics, 22: 361-81.

Shambaugh, J. (2004). 'The Effects of Fixed Exchange Rates on Monetary Policy'.Quarterly Journal of Economics, 119 (1): 301-52. 
Tenreyro, S. (2001). 'On the Causes and Consequences of Currency Unions’.Unpublished manuscript. Cambridge, MA: Harvard University.

Thursby, M.C., and J.G. Thursby (1987).'Bilateral Trade Flows, the Linder Hypothesis, and Exchange Risk'.Review of Economics and Statistics, 69: 488-95.

Tsangarides, C., and M.S. Qureshi (2008).'Monetary Union Membership in West Africa: A Cluster Analysis’.World Development, 36: 1261-79.

Tsangarides, C., P. Ewenczyk, M. Hulej, and M.S. Qureshi (2009). 'Are Africa's Currency Unions Good for Trade’. IMF Staff Papers, 56: 876-918. 
Table 1: Distribution of regimes in the world and Africa sample (1972-2006)

\begin{tabular}{|c|c|c|c|c|c|}
\hline Total & World & Africa & Currency unions & World & Africa \\
\hline Observations & 177,270 & 71,463 & Observations & 2,121 & 1,460 \\
\hline No. of country pairs & 10,894 & 4,811 & No. of country pairs & 178 & 90 \\
\hline$\%$ of world trade & $100 \%$ & $4.30 \%$ & & & \\
\hline Direct pegs (de jure) & & & Direct pegs (de facto) & & \\
\hline Observations & 1,192 & 490 & Observations & 1,625 & 539 \\
\hline No. of country pairs & 124 & 36 & No. of country pairs & 143 & 40 \\
\hline Indirect pegs (de jure) & & & $\begin{array}{l}\text { Indirect pegs (de } \\
\text { facto) }\end{array}$ & & \\
\hline Observations & 8,092 & 1,211 & Observations & 16,705 & 2,461 \\
\hline No. of country pairs & 1,786 & 402 & No. of country pairs & 2,622 & 620 \\
\hline
\end{tabular}

Source: Authors'calculations. 
Table 2: Benchmark specification results for de jure classification (1972-2006)

\begin{tabular}{|c|c|c|c|c|c|c|}
\hline \multirow{2}{*}{$\begin{array}{l}\text { Sample } \\
\text { Estimation }\end{array}$} & \multicolumn{3}{|c|}{ World } & \multicolumn{3}{|c|}{ Africa } \\
\hline & OLS & CPFE & $H T^{1}$ & OLS & CPFE & $\mathrm{HT}^{1}$ \\
\hline \multirow[t]{2}{*}{$\mathrm{CU}$} & $0.603^{\star \star \star}$ & $0.298^{\star \star *}$ & $0.307^{\star \star \star}$ & $1.191^{\star \star \star}$ & $0.626^{*}$ & $0.713^{\star \star \star}$ \\
\hline & $(0.17)$ & $(0.08)$ & $(0.08)$ & $(0.21)$ & $(0.32)$ & $(0.26)$ \\
\hline \multirow[t]{2}{*}{ Direct peg } & $0.398^{\star \star \star}$ & $0.312^{\star \star \star}$ & $0.309 * * *$ & $0.520 * * \star$ & $0.860 * * *$ & $0.842^{\star * *}$ \\
\hline & $(0.11)$ & $(0.11)$ & $(0.11)$ & $(0.18)$ & $(0.33)$ & $(0.32)$ \\
\hline \multirow[t]{2}{*}{$\log (G D P)$} & $1.126^{\star \star \star}$ & $1.093^{\star \star *}$ & $1.210^{\star \star \star}$ & $1.275^{\star \star \star}$ & $1.548^{\star \star \star}$ & $1.668^{\star \star \star}$ \\
\hline & $(0.01)$ & $(0.07)$ & $(0.05)$ & $(0.02)$ & $(0.15)$ & $(0.09)$ \\
\hline \multicolumn{7}{|l|}{ Log(GDP per } \\
\hline \multirow[t]{2}{*}{ capita) } & 0.0172 & $0.182^{\star \star}$ & $0.117^{*}$ & $-0.0695^{\star \star \star}$ & $-0.510^{\star \star \star}$ & $-0.584^{\star \star \star}$ \\
\hline & $(0.01)$ & $(0.07)$ & $(0.06)$ & $(0.02)$ & $(0.15)$ & $(0.11)$ \\
\hline \multirow[t]{2}{*}{ FTA } & $1.282^{\star \star \star}$ & $0.241 * \star *$ & $0.259 * \star \star$ & $1.706^{\star \star \star}$ & 0.00398 & 0.00308 \\
\hline & $(0.11)$ & $(0.05)$ & $(0.05)$ & $(0.16)$ & $(0.13)$ & $(0.13)$ \\
\hline \multirow[t]{2}{*}{ Current colony } & -0.102 & -0.365 & -0.365 & $-2.878^{\star \star *}$ & $-2.643^{\star * *}$ & $-2.668^{\star * *}$ \\
\hline & $(0.58)$ & $(0.70)$ & $(0.70)$ & $(1.06)$ & $(1.02)$ & $(1.02)$ \\
\hline \multirow[t]{2}{*}{ Log(distance) } & $-1.219^{\star \star \star}$ & & $-2.047^{\star \star \star}$ & $-1.173^{\star \star \star}$ & & $-2.381^{\star \star *}$ \\
\hline & $(0.02)$ & & $(0.24)$ & $(0.05)$ & & $(0.15)$ \\
\hline \multirow[t]{2}{*}{ Common language } & $0.494^{\star * *}$ & & $0.532^{\star \star \star}$ & $0.423^{\star \star \star}$ & & $0.526^{\star \star \star}$ \\
\hline & $(0.05)$ & & $(0.06)$ & $(0.07)$ & & $(0.09)$ \\
\hline \multirow[t]{2}{*}{ Common border } & $0.625^{\star \star \star}$ & & -0.486 & $1.141^{\star \star \star}$ & & 0.160 \\
\hline & $(0.14)$ & & $(0.50)$ & $(0.22)$ & & $(0.35)$ \\
\hline \multirow[t]{2}{*}{ Landlocked } & $-0.305^{\star \star *}$ & & $-0.153^{\star *}$ & $-0.405^{\star \star *}$ & & $-0.338^{* * *}$ \\
\hline & $(0.03)$ & & $(0.06)$ & $(0.05)$ & & $(0.06)$ \\
\hline \multirow[t]{2}{*}{ Island } & $0.123^{\star \star \star}$ & & $0.476^{\star \star \star}$ & $-0.291^{\star \star \star}$ & & $0.446^{\star \star \star}$ \\
\hline & $(0.04)$ & & $(0.09)$ & $(0.07)$ & & $(0.10)$ \\
\hline \multirow[t]{2}{*}{ Log(area) } & $-0.0797^{\star \star *}$ & & -0.0259 & $-0.209^{* \star *}$ & & $-0.378^{\star \star \star *}$ \\
\hline & $(0.01)$ & & $(0.04)$ & $(0.01)$ & & $(0.05)$ \\
\hline \multirow[t]{2}{*}{ Common colony } & $0.756^{\star \star \star}$ & & $1.048^{\star \star \star}$ & 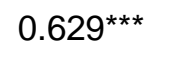 & & $0.407^{\star \star \star}$ \\
\hline & $(0.08)$ & & $(0.12)$ & $(0.10)$ & & $(0.13)$ \\
\hline \multirow[t]{2}{*}{ Ever colony } & $1.221^{\star \star \star}$ & & $1.041^{\star \star \star}$ & $1.637^{\star \star \star}$ & & $1.244^{\star \star \star}$ \\
\hline & $(0.14)$ & & $(0.172)$ & $(0.21)$ & & $(0.29)$ \\
\hline \multirow[t]{2}{*}{ Common country } & $1.603^{\star \star \star}$ & & $2.078^{\star \star \star}$ & & & \\
\hline & $(0.57)$ & & $(0.721)$ & & & \\
\hline \multirow[t]{2}{*}{ Constant } & $-27.18^{\star \star \star}$ & $-40.68^{\star \star \star}$ & $-27.31^{\star \star \star}$ & $-29.98^{\star \star \star}$ & $-51.87^{\star \star \star}$ & $-26.90^{\star \star \star}$ \\
\hline & $(0.36)$ & $(2.64)$ & $(2.77)$ & $(0.66)$ & $(5.16)$ & $(2.08)$ \\
\hline Observations & 177,270 & 177,270 & 177,270 & 71,463 & 71,463 & 71,463 \\
\hline Number of dyads & & 10,894 & 10,894 & & 4,811 & 4,811 \\
\hline R-squared (overall) & 0.72 & 0.61 & & 0.59 & 0.43 & \\
\hline \multicolumn{7}{|l|}{ Hausman-test } \\
\hline$(p \text {-value })^{2}$ & & & 1.00 & & & 1.00 \\
\hline
\end{tabular}


${ }^{1}$ Variables instrumented: CU, Direct peg, Log(GDP), Log(GDP per capita), Log(distance), FTA.

${ }^{2}$ Volatility refers to long-run volatility computed over 36-month horizon.

${ }^{3}$ Hausman-test applied to the difference between the FE and HT estimators.

Source: Authors' calculations. 
Table 3: Benchmark specification results for de facto classification (1972-2006)

\begin{tabular}{|c|c|c|c|c|c|c|}
\hline \multirow{2}{*}{$\begin{array}{l}\text { Sample } \\
\text { Estimation }\end{array}$} & \multicolumn{3}{|c|}{ World } & \multicolumn{3}{|c|}{ Africa } \\
\hline & OLS & CPFE & $H T^{1}$ & OLS & CPFE & $\mathrm{HT}^{1}$ \\
\hline \multirow[t]{2}{*}{$\mathrm{CU}$} & $0.603^{\star \star \star}$ & $0.302^{\star \star \star}$ & $0.311^{\star \star \star}$ & $1.191^{\star \star \star}$ & $0.626^{*}$ & $0.714^{\star \star \star}$ \\
\hline & $(0.17)$ & $(0.08)$ & $(0.08)$ & $(0.21)$ & $(0.32)$ & $(0.26)$ \\
\hline \multirow[t]{2}{*}{ Direct peg } & $0.389^{\star \star \star}$ & $0.339 * * \star$ & $0.336^{\star \star \star}$ & $0.470^{\star \star \star}$ & $0.791^{\star \star \star}$ & $0.778^{\star \star *}$ \\
\hline & $(0.10)$ & $(0.10)$ & $(0.10)$ & $(0.16)$ & $(0.27)$ & $(0.26)$ \\
\hline \multirow[t]{2}{*}{$\log (G D P)$} & $1.126^{\star \star \star}$ & $1.092^{\star \star \star}$ & $1.209^{\star \star \star}$ & $1.275^{\star \star \star}$ & $1.549^{\star \star \star}$ & $1.669^{\star \star \star}$ \\
\hline & $(0.01)$ & $(0.07)$ & $(0.05)$ & $(0.02)$ & $(0.15)$ & $(0.09)$ \\
\hline \multirow[t]{2}{*}{ Log(GDP per capita) } & 0.017 & $0.183^{\star *}$ & $0.117^{*}$ & $-0.069^{\star \star \star}$ & $-0.511^{\star \star \star}$ & $-0.584^{\star \star \star}$ \\
\hline & $(0.01)$ & $(0.07)$ & $(0.06)$ & $(0.02)$ & $(0.15)$ & $(0.11)$ \\
\hline \multirow[t]{2}{*}{ FTA } & $1.282^{\star \star \star}$ & $0.242^{\star \star \star}$ & $0.261^{\star \star \star}$ & $1.705^{\star \star \star}$ & 0.004 & 0.003 \\
\hline & $(0.11)$ & $(0.05)$ & $(0.05)$ & $(0.16)$ & $(0.13)$ & $(0.13)$ \\
\hline \multirow[t]{2}{*}{ Current colony } & -0.101 & -0.364 & -0.363 & $-2.893^{\star \star \star}$ & $-2.644^{\star \star \star}$ & $-2.669^{\star \star \star}$ \\
\hline & $(0.58)$ & $(0.70)$ & $(0.70)$ & $(1.06)$ & $(1.02)$ & $(1.02)$ \\
\hline \multirow[t]{2}{*}{ Log(distance) } & $-1.219^{\star \star \star}$ & & $-2.047^{\star \star \star}$ & $-1.173^{\star \star \star}$ & & $-2.381^{\star \star \star}$ \\
\hline & $(0.02)$ & & $(0.24)$ & $(0.05)$ & & $(0.15)$ \\
\hline \multirow[t]{2}{*}{ Common language } & $0.494^{\star \star \star}$ & & $0.531^{\star \star \star}$ & $0.423^{\star \star \star}$ & & $0.525^{\star \star \star}$ \\
\hline & $(0.05)$ & & $(0.06)$ & $(0.07)$ & & $(0.09)$ \\
\hline \multirow[t]{2}{*}{ Common border } & $0.621^{\star * \star}$ & & -0.488 & $1.141^{\star \star \star}$ & & 0.160 \\
\hline & $(0.14)$ & & $(0.50)$ & $(0.22)$ & & $(0.35)$ \\
\hline \multirow[t]{2}{*}{ Landlocked } & $-0.306^{\star \star \star}$ & & $-0.153^{\star \star}$ & $-0.405^{\star \star \star}$ & & $-0.338^{\star \star \star}$ \\
\hline & $(0.03)$ & & $(0.06)$ & $(0.05)$ & & $(0.06)$ \\
\hline \multirow[t]{2}{*}{ Island } & $0.122^{\star \star \star}$ & & $0.475^{\star \star \star}$ & $-0.291^{\star \star \star}$ & & $0.446^{\star \star \star}$ \\
\hline & $(0.04)$ & & $(0.09)$ & $(0.07)$ & & $(0.10)$ \\
\hline \multirow[t]{2}{*}{ Log(area) } & $-0.080^{\star * \star}$ & & -0.026 & $-0.209^{\star \star *}$ & & $-0.378^{\star \star \star}$ \\
\hline & $(0.01)$ & & $(0.04)$ & $(0.01)$ & & $(0.05)$ \\
\hline \multirow[t]{2}{*}{ Common colony } & $0.755^{\star \star \star}$ & & $1.048^{\star \star \star}$ & $0.629^{\star \star \star}$ & & $0.407^{\star \star \star}$ \\
\hline & $(0.08)$ & & $(0.12)$ & $(0.10)$ & & $(0.13)$ \\
\hline \multirow[t]{2}{*}{ Ever colony } & $1.221^{\star \star \star}$ & & $1.037^{\star \star \star}$ & $1.654^{\star \star \star}$ & & $1.263^{\star \star \star}$ \\
\hline & $(0.14)$ & & $(0.17)$ & $(0.20)$ & & $(0.28)$ \\
\hline \multirow[t]{2}{*}{ Common country } & $1.601^{\star \star \star}$ & & $2.080^{\star \star \star}$ & & & \\
\hline & $(0.57)$ & & $(0.72)$ & & & \\
\hline \multirow[t]{2}{*}{ Constant } & $-27.15^{\star \star \star}$ & $-40.66^{\star \star \star}$ & $-27.29^{\star \star \star}$ & $-29.97^{\star \star \star}$ & $-51.92^{\star \star \star}$ & $-26.90^{\star \star \star}$ \\
\hline & $(0.36)$ & $(2.64)$ & $(2.77)$ & $(0.66)$ & $(5.157)$ & $(2.081)$ \\
\hline Observations & 177,270 & 177,270 & 177,270 & 71,463 & 71,463 & 71,463 \\
\hline Number of dyads & & 10,894 & 10,894 & & 4,811 & 4,811 \\
\hline R-squared (overall) & 0.72 & 0.61 & & 0.59 & 0.43 & \\
\hline \multicolumn{7}{|l|}{ Hausman-test } \\
\hline$(p \text {-value })^{2}$ & & & 1.00 & & & 1.00 \\
\hline
\end{tabular}

Notes: see Table 2.

Source: Authors' calculations. 
Table 4: Extended specification results for de jure classification (1972-2006)

\begin{tabular}{|c|c|c|c|c|c|c|c|c|}
\hline \multirow[b]{2}{*}{ VARIABLES } & \multicolumn{4}{|c|}{ World } & \multicolumn{4}{|c|}{ Africa } \\
\hline & CPFE & $\mathrm{HT}$ & CPFE & $\mathrm{HT}^{1}$ & CPFE & $\mathrm{HT}$ & CPFE & $\mathrm{HT}^{1}$ \\
\hline \multirow[t]{2}{*}{$\mathrm{CU}$} & $0.358^{\star \star *}$ & $0.369 * \star \star$ & $0.316^{\star \star *}$ & $0.332^{\star \star \star}$ & $0.614^{*}$ & $0.678 * \star \star$ & $0.623^{\star}$ & $0.694^{\star \star \star}$ \\
\hline & $(0.08)$ & $(0.08)$ & $(0.08)$ & $(0.08)$ & $(0.32)$ & $(0.26)$ & $(0.32)$ & $(0.26)$ \\
\hline \multirow[t]{2}{*}{ Direct peg } & $0.316^{\star \star \star}$ & $0.312^{\star \star \star}$ & $0.306^{\star \star \star}$ & $0.303^{\star \star \star}$ & $0.876^{\star \star \star}$ & $0.853^{\star \star \star}$ & $0.883^{\star \star \star}$ & $0.861^{\star \star \star}$ \\
\hline & $(0.11)$ & $(0.11)$ & $(0.11)$ & $(0.11)$ & $(0.33)$ & $(0.32)$ & $(0.33)$ & $(0.32)$ \\
\hline \multirow[t]{2}{*}{ Volatility $^{2}$} & $-0.253^{\star * *}$ & $-0.246^{\star \star \star}$ & $-0.254^{\star * *}$ & $-0.245^{\star \star \star}$ & $-0.344^{\star \star \star}$ & $-0.333^{* * *}$ & $-0.344^{\star \star \star}$ & $-0.334^{\star * \star}$ \\
\hline & $(0.03)$ & $(0.03)$ & $(0.03)$ & $(0.03)$ & $(0.05)$ & $(0.05)$ & $(0.05)$ & $(0.05)$ \\
\hline \multirow[t]{2}{*}{ Indirect peg } & & & $-0.152^{\star \star \star}$ & $-0.149 * \star \star$ & & & $0.175^{\star}$ & $0.189 * \star$ \\
\hline & & & $(0.04)$ & $(0.04)$ & & & $(0.09)$ & $(0.09)$ \\
\hline \multirow[t]{2}{*}{$\log (G D P)$} & $1.061^{\star \star \star}$ & $1.191^{* * *}$ & $1.039 * * *$ & $1.193^{\star \star \star}$ & $1.470^{\star \star \star}$ & $1.638^{* * *}$ & $1.486^{\star \star \star}$ & $1.647^{\star \star \star}$ \\
\hline & $(0.07)$ & $(0.05)$ & $(0.07)$ & $(0.05)$ & $(0.15)$ & $(0.08)$ & $(0.15)$ & $(0.08)$ \\
\hline \multicolumn{9}{|l|}{ Log(GDP per } \\
\hline \multirow[t]{2}{*}{ capita) } & $0.193^{\star \star \star}$ & $0.119^{*}$ & $0.214^{\star \star *}$ & $0.127^{\star \star}$ & $-0.463^{\star \star \star}$ & $-0.570^{\star \star \star}$ & $-0.476^{\star \star \star}$ & $-0.578^{\star \star *}$ \\
\hline & $(0.07)$ & $(0.06)$ & $(0.07)$ & $(0.06)$ & $(0.15)$ & $(0.11)$ & $(0.15)$ & $(0.109)$ \\
\hline \multirow[t]{2}{*}{ FTA } & $0.234^{\star \star \star}$ & $0.254^{\star \star \star}$ & $0.248^{\star \star \star}$ & $0.268^{\star \star \star}$ & 0.0198 & 0.0139 & 0.0188 & 0.0159 \\
\hline & $(0.05)$ & $(0.05)$ & $(0.05)$ & $(0.05)$ & $(0.13)$ & $(0.13)$ & $(0.133)$ & $(0.13)$ \\
\hline \multirow[t]{2}{*}{ Current colony } & -0.371 & -0.371 & -0.376 & -0.383 & $-2.640^{\star \star}$ & $-2.676^{\star \star}$ & $-2.631^{\star \star}$ & $-2.664^{\star \star}$ \\
\hline & $(0.70)$ & $(0.70)$ & $(0.70)$ & $(0.70)$ & $(1.05)$ & $(1.04)$ & $(1.05)$ & $(1.04)$ \\
\hline \multirow[t]{2}{*}{ Log(distance) } & & $-2.133^{\star \star \star}$ & & $-1.809^{\star \star *}$ & & $-2.370^{\star \star \star}$ & & $-2.355^{\star \star \star}$ \\
\hline & & $(0.24)$ & & $(0.13)$ & & $(0.15)$ & & $(0.15)$ \\
\hline \multirow[t]{2}{*}{ Common language } & & $0.519 * \star \star$ & & $0.549 * \star \star$ & & $0.531^{\star \star \star}$ & & $0.528 * \star \star *$ \\
\hline & & $(0.06)$ & & $(0.05)$ & & $(0.09)$ & & $(0.09)$ \\
\hline \multirow[t]{2}{*}{ Common border } & & -0.660 & & -0.0145 & & 0.144 & & 0.170 \\
\hline & & $(0.50)$ & & -0.305 & & $(0.35)$ & & -0.35 \\
\hline
\end{tabular}




\begin{tabular}{|c|c|c|c|c|c|c|c|c|}
\hline Landlocked & & $\begin{array}{l}-0.181^{\star \star \star} \\
(0.06)\end{array}$ & & $\begin{array}{l}-0.155^{\star \star \star} \\
(0.05)\end{array}$ & & $\begin{array}{l}-0.356^{\star \star \star} \\
(0.06)\end{array}$ & & $\begin{array}{l}-0.355^{\star \star \star} \\
(0.06)\end{array}$ \\
\hline \multirow[t]{2}{*}{ Island } & & $0.496^{\star \star \star}$ & & $0.374^{\star \star \star}$ & & $0.431^{\star \star \star}$ & & $0.431^{\star * *}$ \\
\hline & & $(0.09)$ & & $(0.07)$ & & $(0.10)$ & & $(0.10)$ \\
\hline \multirow[t]{2}{*}{ Log(area) } & & -0.013 & & -0.0279 & & $-0.360^{\star \star \star}$ & & $-0.365^{\star \star \star}$ \\
\hline & & $(0.04)$ & & $(0.03)$ & & $(0.05)$ & & $(0.05)$ \\
\hline \multirow[t]{2}{*}{ Common colony } & & $0.994^{\star \star \star}$ & & $1.076^{\star \star \star}$ & & $0.394^{\star \star \star}$ & & $0.395^{\star \star \star}$ \\
\hline & & $(0.12)$ & & $(0.10)$ & & $(0.13)$ & & $(0.13)$ \\
\hline \multirow[t]{2}{*}{ Ever colony } & & $1.080^{\star \star \star}$ & & $1.070 * \star \star$ & & $1.300^{\star \star \star}$ & & $1.298^{\star \star \star}$ \\
\hline & & $(0.17)$ & & $(0.17)$ & & $(0.28)$ & & $(0.28)$ \\
\hline \multirow[t]{2}{*}{ Common country } & & $2.142^{\star \star \star}$ & & $2.007^{\star \star \star}$ & & & & \\
\hline & & $(0.72)$ & & $(0.72)$ & & & & \\
\hline \multirow[t]{2}{*}{ Constant } & $-39.26^{\star \star \star}$ & $-26.00^{* \star *}$ & $-38.55^{\star \star \star}$ & $-28.64^{\star \star \star}$ & $-48.87^{\star \star \star}$ & $-26.19 * \star \star *$ & $-49.41^{\star \star \star}$ & $-26.48^{\star \star *}$ \\
\hline & $(2.64)$ & $(2.77)$ & $(2.65)$ & $(1.71)$ & $(5.17)$ & $(2.06)$ & $(5.16)$ & $(2.06)$ \\
\hline Observations & 177,270 & 177,270 & 177270 & 177270 & 71,463 & 71,463 & 71,463 & 71,463 \\
\hline Number of dyads & 10,894 & 10,894 & 10,894 & 10,894 & 4,811 & 4,811 & 4,811 & 4,811 \\
\hline R-squared (overall) & 0.61 & & 0.61 & & 0.43 & & 0.43 & \\
\hline \multicolumn{9}{|l|}{ Hausman-test } \\
\hline$(p-\text { value })^{3}$ & & 0.46 & & 0.78 & & 1.00 & & 1.00 \\
\hline
\end{tabular}

Notes:see Table 2.

Source: Authors' calculations. 
Table 5:Extended specification results for de facto classification (1972-2006)

\begin{tabular}{|c|c|c|c|c|c|c|c|c|}
\hline \multirow[b]{2}{*}{ VARIABLES } & \multicolumn{4}{|c|}{ World } & \multicolumn{4}{|c|}{ Africa } \\
\hline & CPFE & $\mathrm{HT}$ & CPFE & $\mathrm{HT}^{1}$ & CPFE & $\mathrm{HT}$ & CPFE & $\mathrm{HT}^{1}$ \\
\hline \multirow[t]{2}{*}{$\mathrm{CU}$} & $0.363^{\star \star \star}$ & $0.373^{\star \star \star}$ & $0.291^{\star \star \star}$ & $0.306^{\star \star \star}$ & $0.614^{\star}$ & $0.678^{\star \star *}$ & $0.617^{\star}$ & $0.673^{\star \star \star}$ \\
\hline & $(0.08)$ & $(0.08)$ & $(0.08)$ & $(0.08)$ & $(0.32)$ & $(0.26)$ & $(0.32)$ & $(0.26)$ \\
\hline \multirow[t]{2}{*}{ Direct peg } & $0.344^{\star \star \star}$ & $0.341^{\star \star \star}$ & $0.329^{\star \star \star \star}$ & $0.327^{\star \star \star *}$ & $0.809 * \star \star$ & $0.793^{\star \star \star}$ & $0.811^{\star \star \star}$ & $0.795^{\star \star \star}$ \\
\hline & $(0.10)$ & $(0.10)$ & $(0.10)$ & $(0.10)$ & $(0.27)$ & $(0.26)$ & $(0.27)$ & $(0.26)$ \\
\hline \multirow[t]{2}{*}{ Volatility $^{2}$} & $-0.254^{\star * \star}$ & $-0.246^{\star \star \star}$ & $-0.249 * * \star$ & $-0.240^{\star \star \star}$ & $-0.344^{\star \star \star}$ & $-0.333^{\star \star \star}$ & $-0.346^{\star \star \star}$ & $-0.335^{\star \star \star}$ \\
\hline & $(0.03)$ & $(0.03)$ & $(0.03)$ & $(0.03)$ & $(0.05)$ & $(0.05)$ & $(0.05)$ & $(0.05)$ \\
\hline \multirow[t]{2}{*}{ Indirect peg } & & & $-0.228^{\star \star \star}$ & $-0.228^{\star \star \star}$ & & & 0.046 & 0.046 \\
\hline & & & $(0.03)$ & $(0.03)$ & & & $(0.07)$ & $(0.07)$ \\
\hline \multirow[t]{2}{*}{$\log (G D P)$} & $1.060^{\star \star *}$ & $1.190 * * \star$ & $1.027^{\star \star \star}$ & $1.175^{\star \star \star}$ & $1.471^{\star \star \star}$ & $1.639 * \star \star$ & $1.477^{\star \star \star}$ & $1.637^{\star \star \star}$ \\
\hline & $(0.07)$ & $(0.05)$ & $(0.07)$ & $(0.05)$ & $(0.15)$ & $(0.08)$ & $(0.15)$ & $(0.08)$ \\
\hline \multirow{2}{*}{$\begin{array}{l}\text { Log(GDP per } \\
\text { capita) }\end{array}$} & $0.194^{\star \star *}$ & $0.120^{*}$ & $0.228^{\star \star *}$ & $0.146^{\star \star}$ & $-0.464^{\star \star *}$ & $-0.570^{* \star *}$ & $-0.469 * * *$ & $-0.566^{\star \star *}$ \\
\hline & $(0.07)$ & $(0.06)$ & $(0.07)$ & $(0.06)$ & $(0.15)$ & $(0.11)$ & $(0.15)$ & $(0.11)$ \\
\hline \multirow[t]{2}{*}{ FTA } & $0.236^{\star \star *}$ & $0.255^{\star \star \star}$ & $0.262^{\star \star \star}$ & $0.283^{\star \star \star}$ & 0.0199 & 0.0140 & 0.0203 & 0.0131 \\
\hline & $(0.05)$ & $(0.05)$ & $(0.05)$ & $(0.05)$ & $(0.13)$ & $(0.13)$ & $(0.13)$ & $(0.13)$ \\
\hline \multirow[t]{2}{*}{ Current colony } & -0.369 & -0.369 & -0.382 & -0.387 & $-2.642^{\star \star}$ & $-2.677^{\star \star \star}$ & $-2.639 \star *$ & $-2.672^{\star \star}$ \\
\hline & $(0.70)$ & $(0.70)$ & $(0.70)$ & $(0.70)$ & $(1.05)$ & $(1.04)$ & $(1.05)$ & $(1.04)$ \\
\hline \multirow[t]{2}{*}{ Log(distance) } & & $-2.133^{\star \star \star}$ & & $-1.884^{\star \star \star}$ & & $-2.371^{\star \star \star}$ & & $-2.389^{\star \star \star}$ \\
\hline & & $(0.24)$ & & $(0.17)$ & & $(0.15)$ & & $(0.15)$ \\
\hline \multirow{2}{*}{$\begin{array}{l}\text { Common } \\
\text { language }\end{array}$} & & $0.518^{\star \star \star}$ & & $0.543^{\star \star \star}$ & & $0.530^{\star \star \star}$ & & $0.529 * \star \star$ \\
\hline & & $(0.06)$ & & $(0.05)$ & & $(0.09)$ & & $(0.09)$ \\
\hline \multirow[t]{2}{*}{ Common border } & & -0.663 & & -0.157 & & 0.144 & & 0.113 \\
\hline & & $(0.50)$ & & $(0.37)$ & & $(0.35)$ & & $(0.35)$ \\
\hline \multirow[t]{2}{*}{ Landlocked } & & $-0.181^{\star \star \star}$ & & $-0.172^{\star \star \star}$ & & $-0.356^{\star \star \star}$ & & $-0.353^{\star \star \star}$ \\
\hline & & $(0.06)$ & & $(0.06)$ & & $(0.06)$ & & $(0.06)$ \\
\hline \multirow[t]{2}{*}{ Island } & & $0.495^{\star \star \star}$ & & $0.388^{\star \star \star}$ & & $0.432^{\star \star \star}$ & & $0.435^{\star \star \star}$ \\
\hline & & $(0.09)$ & & $(0.07)$ & & $(0.10)$ & & $(0.10)$ \\
\hline \multirow[t]{2}{*}{ Log(area) } & & -0.0127 & & -0.0151 & & $-0.360^{\star \star \star}$ & & $-0.359^{\star \star \star}$ \\
\hline & & $(0.04)$ & & $(0.03)$ & & $(0.05)$ & & $(0.05)$ \\
\hline \multirow[t]{2}{*}{ Common colony } & & $0.995^{\star \star \star}$ & & $1.062^{\star \star *}$ & & $0.395^{\star \star *}$ & & $0.396^{\star * *}$ \\
\hline & & $(0.12)$ & & $(0.11)$ & & $(0.126)$ & & $(0.13)$ \\
\hline \multirow[t]{2}{*}{ Ever colony } & & $1.076^{\star \star \star}$ & & $1.062^{\star \star \star}$ & & $1.318^{\star \star \star}$ & & $1.312^{\star \star \star}$ \\
\hline & & $(0.17)$ & & $(0.17)$ & & $(0.275)$ & & $(0.28)$ \\
\hline \multirow[t]{2}{*}{ Common country } & & $2.144^{\star \star \star}$ & & $2.043^{\star \star *}$ & & & & \\
\hline & & $(0.72)$ & & $(0.72)$ & & & & \\
\hline \multirow[t]{2}{*}{ Constant } & $-39.23^{\star \star \star}$ & $-25.98^{\star \star \star}$ & $-38.17^{\star \star \star}$ & $-27.75^{\star \star \star}$ & $-48.91^{\star \star \star}$ & $-26.19^{\star \star \star}$ & $-49.11^{\star \star \star}$ & $-26.05^{\star \star *}$ \\
\hline & $(2.64)$ & $(2.77)$ & $(2.64)$ & $(2.13)$ & $(5.17)$ & $(2.06)$ & $(5.16)$ & $(2.04)$ \\
\hline Observations & 177,270 & 177,270 & 177270 & 177270 & 71,463 & 71,463 & 71463 & 71463 \\
\hline Number of dyads & 10,894 & 10,894 & 10894 & 10894 & 4,811 & 4,811 & 4,811 & 4,811 \\
\hline
\end{tabular}




\begin{tabular}{|c|c|c|c|c|c|}
\hline $\begin{array}{l}\text { R-squared } \\
\text { (overall) }\end{array}$ & 0.61 & 0.61 & 0.43 & 0.43 & 4811 \\
\hline $\begin{array}{l}\text { Hausman-test } \\
\text { (p-value) }\end{array}$ & & & & & 1.00 \\
\hline
\end{tabular}

Notes:see Table 2.

Source: Authors' calculations.

Table 6: Sensitivity analysis for Africa sample (1970-2006)

\begin{tabular}{|c|c|c|c|c|c|c|c|}
\hline & \multicolumn{7}{|c|}{ De jure classification } \\
\hline & $\begin{array}{l}\text { Short-run } \\
\text { volatility }^{1}\end{array}$ & $\begin{array}{l}\text { Indirect } \\
\text { peg }^{2}\end{array}$ & $\begin{array}{l}\text { Quadratic } \\
\text { income }^{3}\end{array}$ & $\begin{array}{l}\text { Quadratic } \\
\text { volatility }^{4}\end{array}$ & $\operatorname{Vol} 2^{5}$ & $\mathrm{SGMM}^{6}$ & Shambaugh $^{7}$ \\
\hline \multirow[t]{2}{*}{$\mathrm{CU}$} & $0.678^{\star \star}$ & $0.652^{\star \star}$ & $0.429 *$ & $0.629 * \star$ & $0.703^{\star \star}$ & $0.580^{\star \star \star}$ & \\
\hline & $(0.27)$ & $(0.26)$ & $(0.24)$ & $(0.26)$ & $(0.26)$ & $(0.20)$ & \\
\hline \multirow[t]{2}{*}{ Direct peg } & $0.839 * \star \star$ & $0.862^{\star \star \star}$ & $0.939 * \star \star$ & $0.857^{\star \star \star}$ & 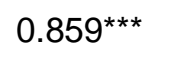 & $0.980^{\star \star \star}$ & \\
\hline & $(0.30)$ & $(0.32)$ & $(0.33)$ & $(0.32)$ & $(0.32)$ & $(0.29)$ & \\
\hline \multirow[t]{2}{*}{ Indirect peg } & $0.184^{\star \star}$ & $0.122^{\star *}$ & $0.191^{\star *}$ & $0.186^{\star \star}$ & $0.189^{\star *}$ & 0.191 & \\
\hline & $(0.09)$ & $(0.05)$ & $(0.09)$ & $(0.09)$ & $(0.09)$ & $(1.45)$ & \\
\hline \multirow[t]{3}{*}{ Volatility $^{a}$} & $-0.238^{\star \star \star}$ & $-0.338^{\star \star \star}$ & $-0.335^{\star \star \star}$ & $-0.835^{\star \star \star}$ & $-0.183^{\star \star \star}$ & -0.011 & \\
\hline & $(0.04)$ & $(0.05)$ & $(0.05)$ & $(0.13)$ & $(0.03)$ & $(0.16)$ & \\
\hline & \multicolumn{7}{|c|}{ De facto classification } \\
\hline \multirow[t]{2}{*}{$\mathrm{CU}$} & $0.659^{\star \star \star}$ & $0.647^{\star \star}$ & $0.417^{\star}$ & $0.611^{\star \star}$ & $0.680^{\star \star \star}$ & $0.768^{\star \star \star}$ & $0.572^{\star \star}$ \\
\hline & $(0.20)$ & $(0.26)$ & $(0.24)$ & $(0.26)$ & $(0.26)$ & $(0.30)$ & $(0.257)$ \\
\hline \multirow[t]{2}{*}{ Direct peg } & $0.774^{\star * *}$ & $0.785^{\star \star *}$ & $0.869 * \star *$ & $0.804^{\star * *}$ & $0.791^{\star \star \star}$ & $0.823^{\star * *}$ & $0.409 * * *$ \\
\hline & $(0.14)$ & $(0.26)$ & $(0.27)$ & $(0.27)$ & $(0.26)$ & $(0.18)$ & $(0.110)$ \\
\hline \multirow[t]{2}{*}{ Indirect peg } & 0.0326 & $-0.0823^{\star}$ & 0.060 & 0.048 & 0.041 & 0.126 & $-0.093^{\star}$ \\
\hline & $(0.04)$ & $(0.05)$ & $(0.07)$ & $(0.07)$ & $(0.07)$ & $(0.41)$ & $(0.06)$ \\
\hline \multirow[t]{2}{*}{ Volatility $^{a}$} & $-0.237^{\star \star \star}$ & $-0.328^{\star \star \star}$ & $-0.337^{\star \star \star}$ & $-0.838^{\star \star \star}$ & $-0.183^{\star \star \star}$ & -0.042 & $-0.333^{\star \star \star}$ \\
\hline & $(0.03)$ & $(0.05)$ & $(0.05)$ & $(0.13)$ & $(0.03)$ & $(0.05)$ & $(0.05)$ \\
\hline Observations & 71318 & 71463 & 71463 & 71463 & 71463 & 64114 & 71463 \\
\hline $\begin{array}{l}\text { Number of } \\
\text { pairs }\end{array}$ & 4811 & 4811 & 4811 & 4811 & 4811 & 4406 & 4811 \\
\hline
\end{tabular}

Notes: *Results obtained from HT estimator; Robust clustered (by dyad) standard errors in parentheses; Time effects and other control variables included in all specifications.

***, ** and * indicate significance at the 1, 5 and 10 per cent levels, respectively.

${ }^{1}$ Short-run volatility over the 12-month horizon.

${ }^{2}$ Deeper indirect peg links (relation=2,3,4 and 5) as in Appendix figure A1.

${ }^{3}$ Includes quadratic terms for log real GDP and real GDP per capita.

${ }^{4}$ Includes quadratic term for exchange rate volatility.

${ }^{5} \mathrm{Vol} 2$ is defined as the standard deviation of the first difference of (logs of) the real exchange rate.

${ }^{6}$ System-GMM dynamic panel estimation.

${ }^{7}$ Using Shambaugh's (2004) de facto exchange rate regime classification.

Source: Authors' calculations. 
Figure 1:Distribution of exchange rate regimes in the world and Africa, 1972-2006 (in per cent of total observations)

(a) IMF de jure classification

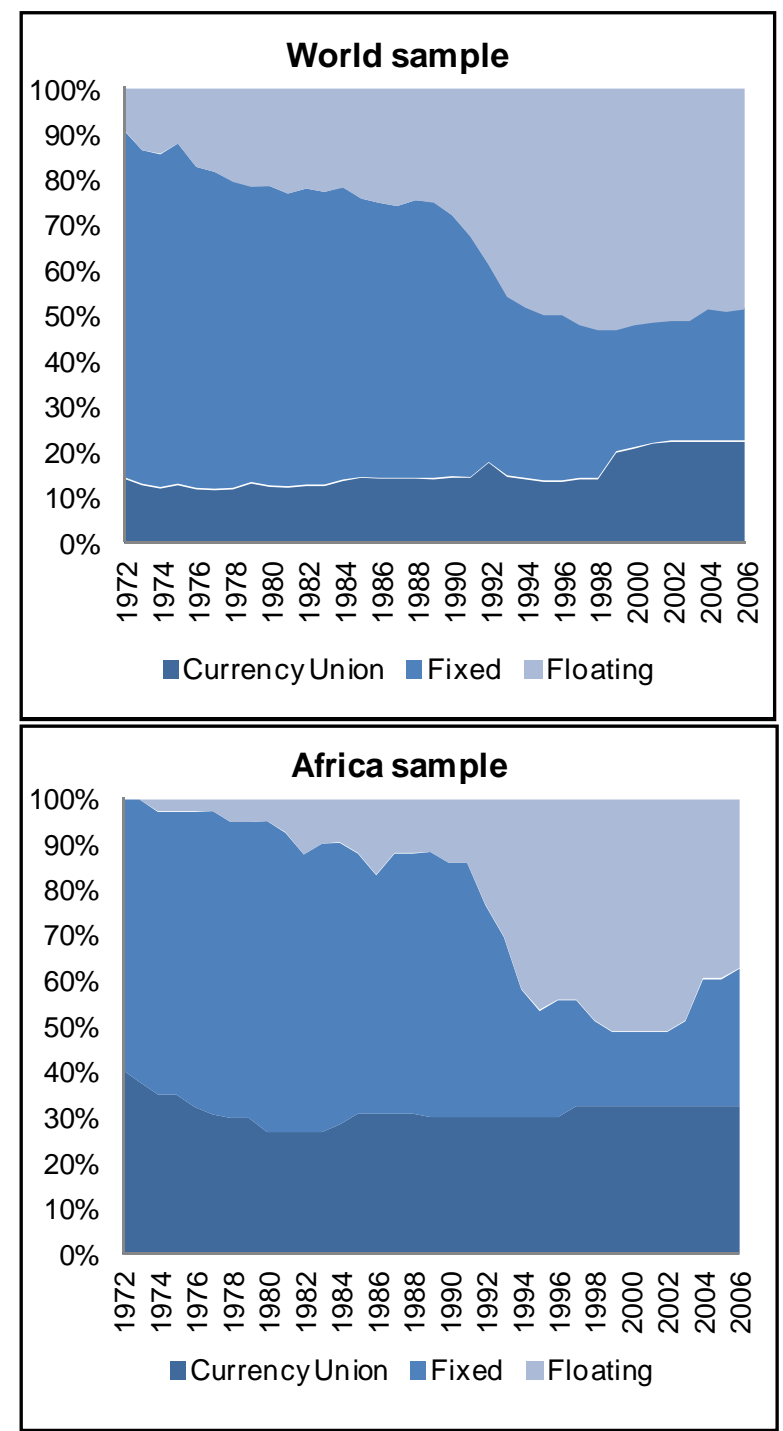


(b) IMF de facto classification

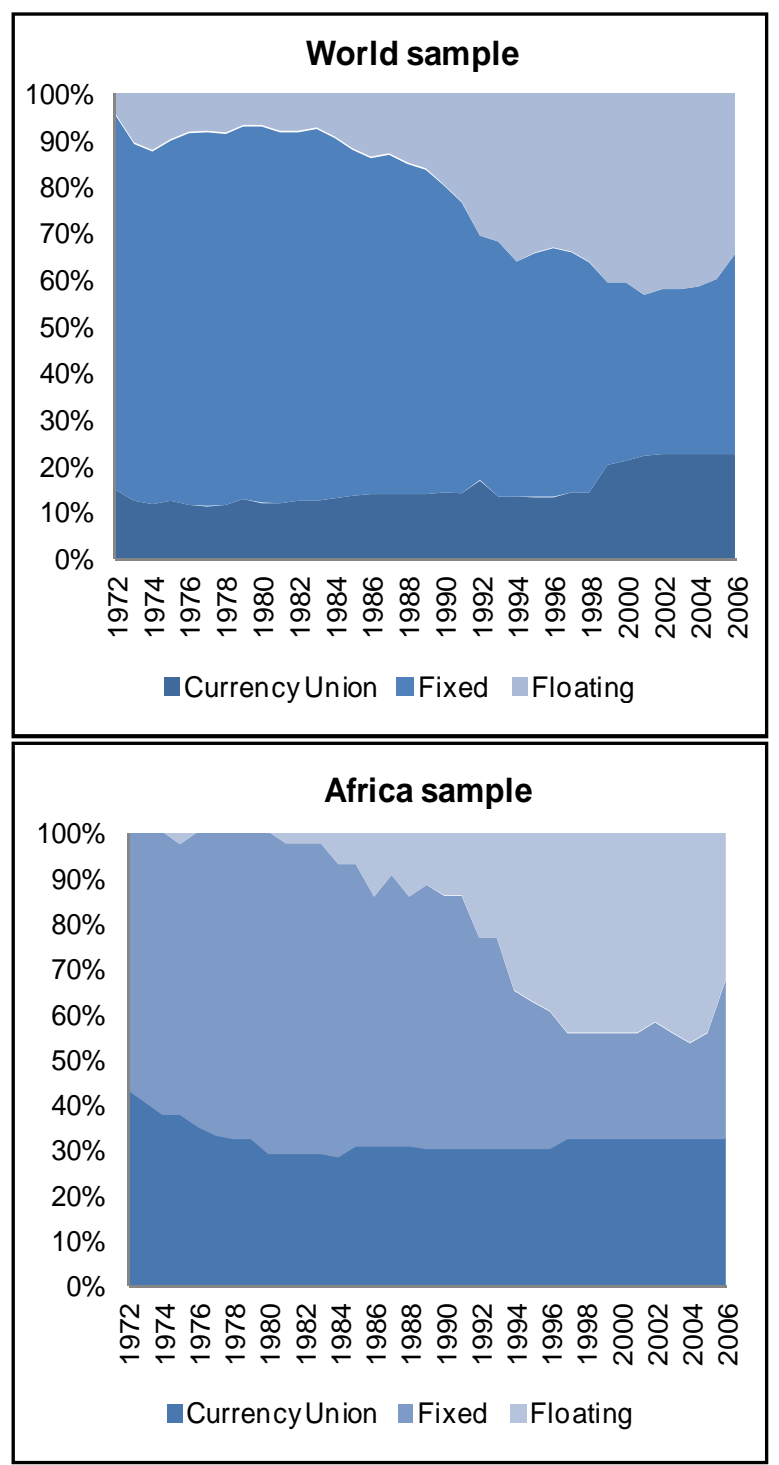

Notes: *Fixed exchange rate regimes here include both conventional pegs as well as intermediate pegs (such as pegs within bands and crawling pegs).

Source: Authors' estimates based on Anderson (2008). 